\title{
sciendo
}

\section{Prestige of the medical profession. Is there a connection between feminization and decreased prestige?}

\begin{abstract}
Introduction. Since the dawn of time, one of the characteristics of the medical profession has been its high prestige. It should be underlined, however, that up until the middle of the 19th century doctors were almost exclusively men. For women, who on the wave of emancipation movements, sought to obtain formal opportunities for becoming a physician, studying medicine and obtaining medical practices were rendered impossible and ultimately hindered due to sex discrimination. Since the beginning of the 20th century, the medical profession has begun to succumb to feminization and women's domination has remained till this day.

Aim. The aim of this article is to present results of research analyzing the position of female doctors in the hierarchy of professional prestige.

Material and methods. Results presented in the article are an outcome of qualitative and quantitative questionnaire studies. Quantitative studies were conducted in 2018 on a representative group of 600 adult Poles. In qualitative research, 29 direct interviews with female doctors were conducted. The research sample was selected using snowball sampling. The respondents were physicians with different seniority who were in the process of specialization or with the title of specialist in the field of eighteen medical specialties.

Results. Among twenty of the evaluated professions, the highest positions in the hierarchy of prestige was obtained by physicians, firefighters and university professors. In direct interviews, female doctors confirmed that their profession enjoys societies' respect; however, the level of respect for numerous reasons has decreased compared to the past. Some of the respondents attributed this fall to feminization of medicine.

Conclusions. A discrepancy was observed between the physicians' and society's opinions. In physicians' opinion, for various reasons (also due to feminization), the prestige of the medical profession has significantly decreased compared to the past.
\end{abstract}

Keywords: hierarchy of prestige, feminization of medicine, physician.

DOI: $10.2478 /$ pjph-2018-0016

\section{INTRODUCTION}

The presented work confines within the trend of sociological analysis pertaining to occupational research; it presents the issue of physicians as a professional group, being the subject of sociological research. The relationship between sociology and medicine was termed by R. Straus "Sociology of medicine" [1].

A profession, defined as a system of activities or tasks that is internally coherent [2], is an explanatory category which, based on various criteria and numerous attributes, determines the individual's social status and characterizes his/her social position. Therefore, in sociological analyzes, a profession is the basis for establishing the social position and ultimately, prestige [2-5].

It is difficult to clearly describe the term prestige. It is the evaluation of perception of various manifestations of respect, esteem or dignity in relation to people, social groups, stances, positions or even institutions [4-6]. Prestige, as a highly valued good, can only be achieved in social relations. In determining the hierarchy of prestige, people apply various criteria; frequently it is a combination of assessment of objective characteristics with a system of values recognized within the society. Prestige is strictly related to material status, education and qualifications, power and position as well as authority. An essential criterion of prestige is also social utility, validity or necessity of protected needs, independence, responsibility and occupational risks, dedication and personal qualifications $[4,5]$.

Research on prestige has been carried out worldwide since 1920s and in Poland since 1958 [4,6]. Analysis of extensive data reveals that the hierarchy of profession's prestige remains quite stable and similar in many of the studied countries, regardless of the type of culture or the level of development. Imperturbably, highly valued are occupations that require high education and specialist qualifications. These professions secure the most important needs of individuals and whole societies, and simultaneously stand out due to high incomes and the possibility of exercising power [4-5]. The highest places in the hierarchy of prestige are occupied by intelligentsia 
professions, and among them, high in various countries, the medical profession [4-7]. What is the current situation of this profession in comparison with others?

The sources of medical prestige should be sought in the distant past, when medicine was closely connected to the sacred sphere and where priests also acted as physicians [8]. With time, medicine began to separate from religion, but treatment remained a privilege of men until the mid-nineteenth century. For many years, women, despite the traditional involvement in the implementation of social roles focused on health and illness in the family and the local community, have been denied the right to acquire medical education. Their path to obtain formal opportunities to practice as a physician was long and difficult. When, during emancipation movements, women were seeking admission to medical schools, they met with intolerance and discrimination $[8,9]$. It was not until the end of the 19th century that they were allowed to study medicine, practice and gain degrees in most European countries and in the USA. Until the World War I, however, male doctors' professional qualifications were more trusted than the qualifications of female doctors who had the same university diplomas [9]. In subsequent years, the possibilities of women's education and work in medicine began to change dynamically. In 1922, women constituted around $10 \%$ of all doctors in Poland. In the post-war period, their participation increased so quickly that in the mid-twentieth century, the profession of a doctor began to undergo feminisation [9]. Currently, women's interest in studying medicine and practicing the medical profession is very high. At the beginning of 2018, they constituted $57.7 \%$ of practicing doctors in Poland [10].

Gender-based differences were analyzed in many publications concerning professional activity and its consequence. Years ago, A. Sarapata, referring to opinions of other sociologists, stated that the professions which feminize, lose prestige [3]. Can it be the case of today's medical professions?

\section{AIM}

The main aim of this article is to present research results, showing the position of a physician in the hierarchy of profession's prestige and analysis of doctor's statements regarding the relationship between the feminization of their professional group and prestige. The study investigates the following research problems 1 . The position of doctors, compared to other professsional groups, according to Poles. 2. The possition of male doctors according to female doctors. 3. Feminization as a factor influencing professional prestige, according to female doctors.

\section{MATERIAL AND METHODS}

Presented data come from quantitative and qualitative surveys. Quantitative research was carried out on behalf of the Independent Medical Sociology Unit of the Medical University of Lublin by the BST Group in 2018, using the CAPI technique (Computer Assisted Personal Interview) on a representative group of 600 Poles, above 18 years of age. The maximum statistical error assumed was $4 \%$. Representativeness, which makes it possible to generalize the data, obtained in the entire population of adult Poles, was determined on the basis of: respondents' gender, their age, education and place of residence. There were $51 \%$ women and $49 \%$ men among the respondents. Respondents up to 29 years old accounted for $17.7 \%$; up to 39 years $-21 \%$; up to 49 years $-17 \%$; up to 59 years $-16.3 \%$; people aged 60 and over constituted $28 \%$. When it comes to education, $2.2 \%$ of respondents described their as primary or gymnasial; $19.3 \%$ - basic vocational; $35.4 \%$ - secondary; $21.8 \%$ - higher undergraduate and $21.3 \%$ - higher master's degrees. When it comes to $5.5 \%$ of the respondents, they lived in villages, the rest lived in cities: up to $20,000(10 \%)$, $20-100$ thousand $(38 \%), 100,000$ to $500,000(37.5 \%)$ and above $500,000(9 \%)$ citizens. Only $2 \%$ of the respondents were in the medical profession. The vast majority positively assessed the state of their own health (very good $-24 \%$, good $-62 \%$, average $-12.7 \%$, bad $1.3 \%$ ) and material status (very good $-11.3 \%$, good $-59.8 \%$, average $-27.7 \%$, bad $-1.2 \%$ ).

In own qualitative research, the technique of free interview was applied. The research sample was selected using the snowball method [11]. As many as 29 interviews were conducted with professionally active physicians who worked in various medical institutions in the Lubelskie province. Conversations, after obtaining the consent of the respondents to register and use the material for scientific purposes, were recorded on a recorder. Research was based on the principle of confidentiality. A well-established theory of $\mathrm{K}$. Charmaz was used to develop the methodological concept of research and analysis of the obtained material. This theory states that, before exploring new subjects, researchers should not elaborate on detailed research problems and hypotheses, and should refrain from thorough reviews of scientific literature, so that previous concepts do not determine the research's own conclusions. It is a method of conducting qualitative research, in which the emphasis is placed on creating a framework or theory through building inductive data based analysis [12].

The respondents were women with various seniority (from 1 to 32 years), who were in the process of specialization or having a specialist title in the field of eighteen medical specialties. Physicians occupied various positions and, depending on the place of work, had or had no academic titles. The respondents included managers of healthcare institutions, women with the academic title of $\mathrm{PhD}$, associate professor or professor. The marital status and the family situation of women also varied. They were single, married, women without children or mothers of one, two, three or four.

Research material obtained during recording interviews was transcribed, coded and data categorization was made. Afterwards several analytical areas were selected and one of them, presented in the results of own research.

\section{RESULTS}

Respondents defined the prestige of twenty professions included in the questionnaire, assessing their level of respect for each of them. In the assessment of each profession, it was necessary to apply a scale from 1 (very small level of respect) to 5 (very high). The results showing the arithmetic mean for particular occupational groups are presented in Figure 1. The highest prestige was given to the profession of physician, firefighter and a university professor. Differences in results between particular occupations were small, their spread between the lowest (3.56) and the highest (4.58) was only 1.02 degrees. As many as $91.3 \%$ of respondents rated the profession of a physician as 4 or 5 , declaring high respect for the profession, $6 \%$ of the respondents chose 3 (average) and $2.7 \%$ - grade 2 (low). None of the respondents pointed to 1 , which indicated a very small level of respect. 


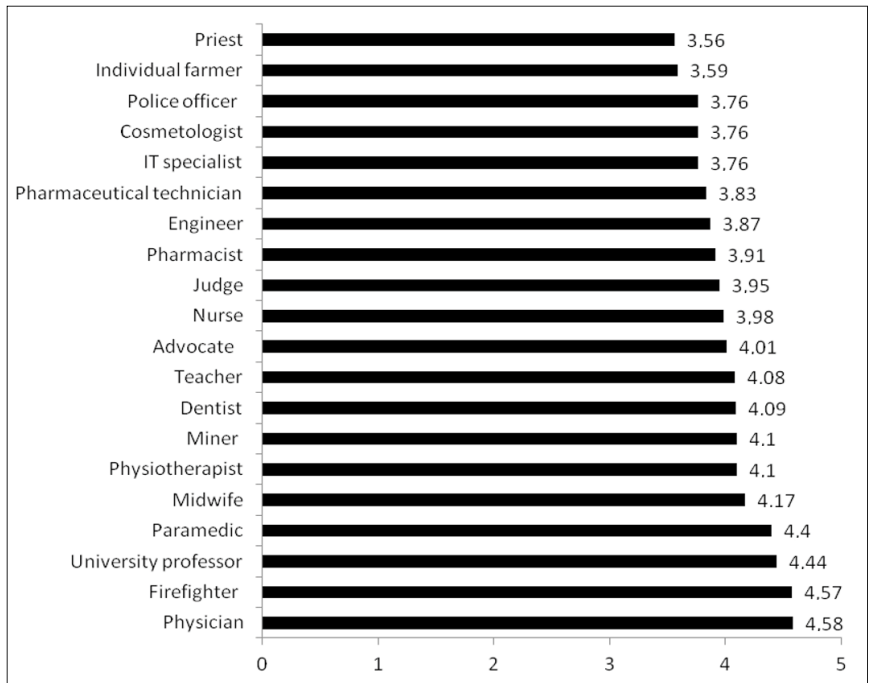

FIGURE 1. Poles opinon on the hierarchy of professioanl prestige based on the arithmetic mean.

Complement of the results of quantitative research, were data from free interviews conducted with female physicians. The respondents answered, among others, for questions about the reasons why women nowadays so willingly choose to become a doctor and whether the feminization of the profession affects its prestige.

According to the respondents, prestige is an important motive for choosing the medical career and ultimately, the profession of a doctor. In addition, women combined prestige with the possibility of obtaining attractive income or certainty of work: "many girls choose medical studies because it is a matter of prestige" [W1], "because the work place is secure... certain... there is a job and besides, it is a prestigious profession" [W7].

In the respondents' opinion, the relationship between feminization of the physicians' profession and its prestige is not unambiguous. Women often paid attention to the fact that their profession has lost prestige over the last few decades. However, those that did not combine this with women's domination, pointed to other reasons, related, for example to: sociopolitical situation and a decline in respect for all intellectual professions, bureaucracy, propagating an idealistic image of a doctor in television series, easy access to medical knowledge on the Internet, unprofessional behavior of doctors or claimant attitudes of patients. The respondents stated that: "this fall in prestige exists for sure, because working for over 30 years I see the current approach of patient. Patients are more restitutionary and demanding"[W8] "Which medical profession has prestige? - None. Who now respects the doctor? no one. Currently, the doctor has a servile value, he has to only and exclusively serve, because it is a health service and no one has respect for the doctor. I don't see respect" [W16].

Female physicians who claimed that the domination of women in medicine could have an impact on a decreased level of respect for the profession, referred to the stereotypical, in the opinion of patients, image of a doctor - a man. In their opinion, "a greater respect among patients is attributed to male compared to female doctors" [W22], "as a patient once told meyou never know whether it is a nurse or a doctor because only women work here" [W1], "in majority of the cases a woman is treated only as a woman, that's it, and what can a woman know? A man has knowledge... and a woman..." [W16].
Respondents associated different treatment of male doctors also depending on their medical specialties. In their opinion, greater respect among patients and their family members is granted to representatives of surgical specialties. "I think that there are specialties, such as surgery, where the patient sees a woman and feels uncertainty because he believes that she may not be able to handle it (...) my friends also came across such situations where patients are surprised to see a female doctor "you're going to operate on me? Such a girl?" [W27] "My work requires that I collaborate or consult various things with colleagues - practitioners, with them parents talk differently (...) If I approach a parent with a male colleague, because there is a need for the parent to talk to somebody from a different specialty (...), parents talk differently to that doctor, maybe because the doctor is a practitioner and the child's life depends on him, but something depend on me too, let's make a deal, I'm treated differently, maybe not worse but with less concern" [W16].

\section{DISCUSSION}

The profession of a physician, included in the group of intellectual workers, has traditionally been given high esteem in society, especially due to the specialist qualifications and validity of the needs being secured. This is a profession of public trust that is associated with vocation and perceived in terms of profession $[3,4,6,8,16]$.

In Polish research on prestige during the times of the Polish People's Republic, the doctor occupied the second, third or fourth place; most often after a university professor, minister, miner or teacher. In representative studies carried out after the transformational breakthrough in 1991, 1995, 1999, 2006 the physician held the second position after university professor, and in 2004 and 2008, the doctor's prestige in professional hierarchy dropped to the fifth place (after university professor, miner, nurse teacher and university professor, firefighter, miner and a nurse, respectively). The above-mentioned studies used the same questions and the obtained results were averaged, enabling cross study comparison [4]. In 2013, 30 professions were analyzed in terms of prestige; the physician came in eighth position after fireman, university professor, skilled worker, miner, engineer working in a factory and a teacher [7].

In representative own studies, the position of a physician due to prestige has been particularly exposed. This may result from the difficulties in obtaining a doctor's visit and simultaneously medical aid in Poland. Many physicians have moved to work abroad since 2004 and there is still a lot of interest in emigration in this professional group. In a situation of an increased need of treatment and medical care, e.g. due to the aging of the society, there is a real risk of insufficient amount of doctors. In such a situation, high level of respect is unquestionable. Noteworthy is the fact that female doctors, aware of the high prestige of the profession, noticed its significant decrees. Noteworthy, however, is the fact that doctors in qualitative research, aware of the high prestige of the profession, noticed in their own relations with patients, a significant decrease in respect for their work. This is indicated by a discrepancy between declarations regarding respect for the profession and real attitudes of patients towards doctors.

The implementation of professional practice by women who gave free interviews confirms a constant perception of them through the prism of traditional gender roles and stereotypes. 
The results of our own research show different professional situations of women and men, just as numerous publications on the specificity of work of female doctors [9,13-16].

\section{CONCLUSIONS}

1. Poles recognized that, among professions subjected to evaluation, doctors have the highest prestige in society.

2. According to female doctors, the prestige of their profession is reduced within the society for various reasons. One of them is feminization. Women drew attention to the fact that patients and their relatives give men (especially in surgical specialties) greater respect than women.

\section{REFERENCES}

1. Straus R. Medical sociology: a personal fifty year perspective. J Health Soc Behav. 1999;2:103-10.

2. Szczepański J. Czynniki kształtujące zawód i strukturę zawodową In: A. Sarapata (ed). Socjologia zawodów. Warszawa: Książka i Wiedza; 1965. p. 11-24.

3. Sarapata A. Zawód jako wyznacznik miejsca w społeczeństwie In: A. Sarapata (ed). Socjologia zawodów. Warszawa: Książka i Wiedza; 1965. p. 143-75.

4. Domański H. Prestiż zawodów w obliczu zmian społecznych: 1958-2008. Studia Socjol. 2010;4:79-121.

5. Domański H. Prestiż. Toruń: Wydawnictwo Naukowe Uniwersytetu Mikołaja Kopernika; 2012.

6. Tobiasz-Adamczyk B, Bajka J, Marmon G. Wybrane elementy socjologii zawodów medycznych. Kraków: Collegium Medicum UJ; 1996.

7. Cybulska A. Prestiż zawodów. CBOS. Komunikat z badań. BS/164/2013. https://www.cbos.pl/SPISKOM.POL/2013/K_164_13.PDF (dostęp dnia: 30.03.2018.).

8. Szumowski W. Propedeutyka lekarska. Kraków: Akademia Medyczna im. Mikołaja Kopernika w Krakowie; 1992.

9. Janicka I. Medycynierki, medyczki, lekarki- dyskryminacja naukowa i zawodowa kobiet-lekarek w wybranych państwach europejskich oraz USA w XIX wieku. Studia Historica Gedanensia. 2013;4:69-91.

10. Zestawienie liczbowe lekarzy i lekarzy dentystów wg wieku, płci i tytułu zawodowego $\mathrm{z}$ uwzględnieniem podziału na lekarzy wykonujących i niewykonujących zawod. Naczelna Izba Lekarska. https://www.nil.org. pl/__data/assets/pdf_file/0017/124505/Zestawienie-nr-03.pdf(dostępdnia: 30.03.2018.).

11. Babbie E. Podstawy badań społecznych. Warszawa: Wydawnictwo Naukowe PWN; 2008.

12. Charmaz K. Teoria ugruntowana. Praktyczny przewodnik po analizie jakościowej. Warszawa: Wydawnictwo Naukowe PWN; 2009.

13. Hølge-Hazelton B, Malterud K. Gender in medicine - does it matter? Scand J Public Health. 2009;2:139-45.

14. Williams ChL. The glass escalator, revisited: Gender inequality in neoliberal times, SWS Feminist Lecturer. Gender \& Society. 2013;5:609-629.

15. Ramakrishnan A, Sambuco D, Jagsi R. Participation of women in the medical profession: insights from experiences in Japan, Scandinavia, Russia and Eastern Europe. J Womens Health (Larchmt). 2014;23:927-34.

16. Norredam M. Album D. Prestige and its significance for medical specialties and diseases. Scand J Public Health. 2007;6:655-61.

\section{Corresponding author}

Dr Renata Bogusz

Independent Medical Sociology Unit, Faculty of Health Sciences

Medical University of Lublin

4-6 Staszica St., 20-081 Lublin, Poland

tel.: +48814486963

E-mail: renata.bogusz@umlub.pl 